\title{
PEMEROLEHAN KOSAKATA BAHASA KOREA PADA PEMBELAJAR INDONESIA
}

\author{
Indonesian Adult Learners Acquiring Korean Vocabulary
}

\author{
Amanda Vira Maharani
}

Fakultas Ilmu Budaya, Universitas Brawijaya

amandaviram@gmail.com

\begin{abstract}
Abstrak
Penelitian ini bertujuan untuk mengetahui pengaruh lagu dan video Korea pada kosakata pembelajar Bahasa Korea dewasa melalui komunikasi satu arah. Untuk mengumpulkan data, tiga responden berpartisipasi dalam penamaan gambar dalam Bahasa Korea dan kuesioner digunakan untuk mengetahui frekuensi peserta dalam mendengarkan lagu Korea dan menonton video Korea. Hasil penelitian menunjukkan bahwa memperoleh kosakata pada pelajar dewasa sulit karena motivasi dan faktor usia. Semua peserta penelitian ini telah terpapar ke media berkonten Korea selama lebih dari lima tahun, namun tidak satupun dari mereka mendapat nilai sempurna pada tes kosakata, tetapi mereka mendapat motivasi yang berbeda untuk belajar Bahasa Korea. Dapat disimpulkan bahwa semakin tinggi motivasi pada pelajar adalah hasil yang lebih baik pelajar dapatkan. Pemerolehan kosakata Bahasa Korea dengan mendengarkan lagu-lagu Korea dan menonton video Korea adalah mungkin namun tidak mudah diperoleh oleh pembelajar dewasa.
\end{abstract}

Kata-kata Kunci: pembelajar dewasa; kosakata Bahasa Korea; pemerolehan kosakata

\begin{abstract}
This study aims to find out the effects of Korean songs and videos on vocabulary size of adult Korean language learners through one-way communication. To collect the data, three respondents participated in a picture-naming task in Korean and questionnaire is used to know the frequency of the participants in listening to Korean songs and watching Korean videos. The result showed that acquiring vocabularies on adult learners is difficult because of motivation and age factors. All participants of this study have exposed to Korean content media for more than five years, yet none of them got a perfect score on vocabulary test, but they got different motivations for learning Korean. It can be concluded, the higher the motivation on learner is the better result the learner's got. Korean vocabulary acquisition by listening to Korean songs and watching Korean videos is possible yet not easily acquired by adult learners.
\end{abstract}

Key Words: adult learners, Korean vocabulary, vocabulary acquisition

How to Cite: Maharani, Amanda Vira. (2019). Pemerolehan Kosakata Bahasa Korea pada Pembelajar Dewasa Indonesia. Ranah: Jurnal Kajian Bahasa, $8 \quad$ (2), 255-266. doi: https://doi.org/10.26499/rnh.v8i2.962 


\section{INTRODUCTION}

Korea in this era has expanded its culture into international community and it can be said it has reached as successful as Hollywood and Bollywood. Globalization of Korean pop culture called Hallyu is now succeed invading in every sector especially youth sector, including in Indonesia (Nugroho, 2010). The most influential things of Hallyu brought into Indonesia are Korean drama and Korean pop. It is not a strange thing to hear Korean song when someone is entering a store or watching Korean drama broadcasted by national or local TV. Another evidence of Hallyu in Indonesia is the establishment of Korean Study Program in many universities (Nugroho, 2010). By these phenomena, many people now are listening to Korean songs and watching Korean videos as part of their life or become enganged to Korean culture itself. At this point, people who are interested in Korean culture are subconsciously learning Korean, through Korean songs and videos.

Acquiring is different process with learning since acquiring is more subconscious process. There are so many studies on how to develop certain skills through formal and informal education, such as school, language course, and community. A previous study by Purwiyanti, Suwandi, \& Andayani (2017) explored the strategy used by foreign language learners who learn Indonesian that communication strategy that really useful for them are verbal communication (in the form of spoken and written utterances) and non-verbal communication (using gestures to convey the information he wants to convey to his speech partners).

Acquiring language can be an intrapersonal development or one-way communication and without any formal or informal education. Dulay, Burt, and Krashen (1982) stated that one-way communication occurred when the learners listen or read the target language, but there is no response. The learners can engage and trigger themselves to learn a new language with interesting activities or acquiring new language within their activities. Saville-Troike (2006) stated that some of individuals can acquire up to advance level of L2 proficiency without interpersonal communication. The media used in intrapersonal communication can be text and electronic media as social interaction, such as podcast, radio, songs, and videos. Thus by this point, a learner can acquire a new language by listening and or watching a media, such as song and video. 
Second Language Acquisition (SLA) refers to the study of individuals who are learning a language which is different from their first language (Saville-Troike, 2006). Vocabulary acquisition has relation to language acquisition. As the most important element in language, vocabulary has to be mastered by language learners. Hatch and Brown (in Febriana, 2017) state that vocabulary refers to a set of words that speaker may use and Read (in Febriana, 2017) added that vocabulary is individual words' inventory including the words meaning. Acquiring vocabulary can be obtained from listening, reading, writing and also speaking activities, which vocabulary also supports the four skills.

Learning through songs has become the most favored activity in language teaching. Lubliner and Scott (in Teng, 2016) stated that learning through enjoyment contributes to constructing a good vocabulary development, especially on morphological awareness. Songs used in most English language learning and can be used as an effective material for teaching vocabulary (Teng, 2016 and Murphey, 1992). Another material that can be used is movies or videos. Movie is one of the multimedia technologies that can be used to facilitate learners' language acquisition. In this way, implementing videos and audios in learning language is more convenient and entertaining for both teachers and learners (Bintari, 2017).

Throughout this background of study, it is found that rarely to be found any study on Korean language learning through Korean songs and videos. Therefore the researcher would like to conduct a study on whether the adult learners are able to acquire Korean vocabulary through songs and videos within one-way communication. The present study attempts to know if Korean songs and videos are eventually gain the vocabulary size of Korean language learner and what factor that can affect their acquisition process.

\section{THEORY}

In the process of adults' second language acquisition, Krashen (in Deng and Zou, 2016) states that it requires a conscious learning process, which a method to find and correct the error. While, Skinner's greatest contribution to language research is "stimulation-response-enhancement" theory for adults' second language acquisition as well as foreign language teaching, which derived a new teaching method: the audio- 
lingual method (in Deng and Zou, 2016). Deng and Zou (2016) did a study on adults' second language acquisition. The result showed that acquisition itself was difficult and complicated for adults because of some aspects, such as age and motivation. However, adults can use some rules of children's language acquisition to increase the rate of success to acquire second language.

There are many aspects can affect learners in acquiring a new language; two of them are motivation and age. There are three kinds of motivation: integrative motivation, instrumental motivation, and social group identification explained by Dulay, Burt, and Krashen (1982). The first one is integrative motivation. It is a motivation that makes a person able to participate in the life of a community that speaks the language learned. Instrumental motivation is the desire to acquire a language as a tool, for example getting a job or study abroad. The last one is social group identification; it is the desire to acquire a language spoken by a certain social group that the learner identifies. Gardner and Lambert (in Dulay et al., 1982) found that people who have integrative motivation are tended to be more successful than those who have instrumental motivation in learning French. Moreover, a study conducted by Gardner, Smythe, Clement, and Gliksman (in Dulay et al., 1982) found that integrative motivation tended to have higher correlation with oral communication than grades.

There are several factors influencing motivation itself. According to attribution theory by Wiener (in Nadiyah, 2014) there are four factors influencing learners' learning motivation, namely ability, task difficulty, effort, and luck. Ability and effort are internal factors; meanwhile, task difficulty and luck are external factors of the learners. Although ability is included in internal factor; the learners' do not have much control over this factor. In the meantime, another internal factor, effort is a factor that the learners' have a great deal of control. Naturally, as external factors, task difficulty and luck are beyond learners' control.

The second factor that can affect learners in acquiring a language is age. Language is best learned during the early years of childhood as children's brains are more flexible than adults (Hu, 2016). In Dulay et al. (1982), children appear to be more successful in phonological development and native-like accent. Meanwhile, adults are learning faster than children in syntax and morphology. Schumann (2013) stated it is obvious that L2 is not easily acquired by adult. Since children acquire language early 
Pemerolehan Kosakata...

because it is important and necessary, on the other hand, adult language acquisition may not be essential for adults themselves. Johnson and Newport (in $\mathrm{Hu}, 2016$ ) stated that older learners will not have native-like language skills, but will get a great attainment which different from each learner. Therefore, adults do not always have negative traits to be slower in learning a new language than children.

\section{METHOD}

This present study employed a survey research design with a small number of participants investigated a phenomenon in details. The three participants did not take any formal education or course in learning Korean and a native speaker of Indonesian. They learned Korean only through Korean songs and videos. Thus it is best to use case to study to describe actual condition of the participants. The age of the participants is around 23-24 years old.

To measure the vocabulary size, this study used the Peabody Picture Vocabulary Test IV (PPVT-4). Peabody Picture Vocabulary Test is widely used for testing vocabulary for children and adults. PPVT IV itself is a revised and latest version of Peabody Picture Vocabulary Test (Verstegen, 2014). The test consisted of ten pictures of objects and one example picture which are taken from Verstegen (2014) study on receptive vocabulary development of children acquiring Chinese, Swedish, and Korean. The ten test items consisted of eight noun phrases; one verb phrase and one adjective phrase. The ten test items are high-frequency vocabulary, especially in Korean videos. Nation (2001) describes that high-frequency vocabulary is vocabulary that frequently met in the use of language (cited in Hanifah, 2014). The given time is 10 minutes to complete the task. Peabody Picture Vocabulary Test itself is an English vocabulary test. In this present study, the participant will answer it in Korean.

This study also used questionnaire to know the frequency of the participants on listening to Korean songs and watching Korean videos. There are ten questions to measure their frequency of listening to Korean songs and watching Korean videos. It covers: (1) time period exposed to Korean culture media, (2) frequency on listening to Korean songs and watching Korean videos, (3) motivation, (4) Korean Language, (5) Hangeul, (6) Korean vocabulary, (7) video and song, (8) the effectiveness learning 
through song and video, (9) the benefit and loss learning through song and video, and (10) opinion. The questionnaire is written in Indonesian to avoid miss understanding.

The test and questionnaire were presented on Google Sheet. The participants answered the vocabulary test by writing down the answer on a piece of paper and by researcher command to start and finish the test. The given time for vocabulary test is 10 minutes. It is better to write down the answer on the paper rather than to type because it is complicated and it takes more time to find the Hangeul character on the keys. After the participants finished the vocabulary test, they can fill the questionnaire directly on the Google Sheet. Every true answer of vocabulary test was given 10 points and 0 point for wrong answer, in total 100 points. The participants' answers on the questionnaire were to support the result of vocabulary test and to describe their actual condition on learning vocabulary.

\section{DISCUSSION}

\section{Korean Vocabulary Test Results}

For test item number one, Respondent 1 (R1) could answered it right, Respondent 2 (R2) could not answer and Respondent 3 (R3) instead of answering 개:/ge/ (dog), she answer 강아지:/gayadzi/ (puppy). Test item number two, there were none of the participants could answer the question. Test item number three, R1 and R2 could answer it right, but R3 answer 팔:/phal/ (arm), she wrote with 프:/ $\mathrm{p}^{\mathrm{h} /}$ instead of $\forall: / \mathrm{p} /$. Test item number four, only R1 could answer it. Test item number five, all of them got the right answer. Test item number six, R1 got the right answer, R2's answer is wrong, and R3 answer is wrong but it is the most listened to Korean videos. 맘:/mam/ is mom but in videos we could find Korean saying 맘마:/mamma/ to say eating especially when talk to children. Test item number seven, R1 and R2 could answer it right. Number eight, R1 got the right answer, R2 is already got the right answer but she added 줄:/dzul/, R3 is got the idea to write 잎술:/ipsul/ (lips) but she added -:/w/ after 프:/ph/ (이프술:/ip ${ }^{\mathrm{h} u s u l /) . ~ N u m b e r ~ n i n e ~ n o ~ o n e ~ c o u l d ~ a n s w e r ~ i t . ~ T h e ~ l a s t ~ t e s t ~ i t e m, ~ n u m b e r ~ t e n, ~}$ R1's answer is close to the right answer, but she wrote 바랑:/paran/ instead of파란:/pharan/, R2 could not answer, and R3 answer it wrong. 
For test item number one, Respondent 1 (R1) could answer it right, Respondent 2 (R2) could not answer and Respondent 3 (R3) instead of answering 개:/ge/ (dog), she answer 강아지:/ganadzi/ (puppy). Test item number two, there were none of the participants could answer the question. Test item number three, R1 and R2 could

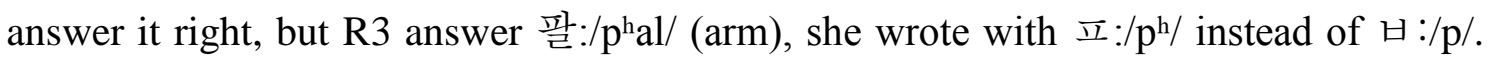
Test item number four, only R1 could answer it. Test item number five, all of them got the right answer. Test item number six, R1 got the right answer, R2's answer is wrong, and R3 answer is wrong but it is the most listened on Korean videos. 맘:/mam/is mom but in videos we could find Korean saying 맘마:/mamma/ to say eating especially when talking to children. Test item number seven, R1 and R2 could answer it right. Number eight, R1 got the right answer, R2 is already got the right answer but she added 줄:/dzul/, R3 is got the idea to write 잎술:/ipsul/ (lips) but she added -:/u/ after 표:/ $\mathrm{p}^{\mathrm{h} /}$ (이프술:/ip ${ }^{\mathrm{h}} \mathrm{usul} /$ ). Number nine no one could answer it. The last test item, number ten, R1's answer is close to the right answer, but she wrote 바랑:/paray/ instead of 파란:/ $\mathrm{p}^{\mathrm{h}}$ aran/, R2 could not answer, and R3 answer it wrong.

Tabel 1

Picture-naming Task Results

\begin{tabular}{|c|c|c|c|c|}
\hline \multirow{2}{*}{$\begin{array}{l}\text { Test } \\
\text { Item }\end{array}$} & \multirow{2}{*}{ Words } & \multicolumn{3}{|c|}{ Answers } \\
\hline & & R1 & $\mathbf{R 2}$ & R3 \\
\hline 1 & Dog - 개 & 개 & - & 강아지 \\
\hline 2 & Spoon - 숟가락 & - & - & - \\
\hline 3 & Foot - 발 & 발 & 발 & 팔 \\
\hline 4 & Duck - 오리 & 오리 & - & - \\
\hline 5 & Shoes - 신발 & 신발 & 신발 & 심발 \\
\hline 6 & To eat - 먹어 & 먹어 & 먹라 & 맘 \\
\hline 7 & Flower - 昡 & 꽃 & 㱞 & 구트 \\
\hline 8 & Mouth - 입 & 입 & 입줄 & 이프술 \\
\hline 9 & Pencil - 연필 & - & - & - \\
\hline 10 & Blue - 파란색 & 바랑색 & - & 너랑 \\
\hline
\end{tabular}

R1 got seven correct answers, one wrong and two unanswered. From the questionnaire, she has been watching Korean videos and listening to Korean songs since senior high school, about seven years and always listening to Korean songs every day and watching Korean videos more than once a week. The reason why she started to learn Korean because she likes some of Korean boy music groups and also the K-TV shows. She wants to know what they are talking about in Korean and has been learning 
Korean for about five years. In her opinion, writing in Korean alphabet (Hangeul) is quite hard, because she enjoys reading rather than writing. If she encountered new vocabulary while watching video or listening to song, she would guess and correlate it with the context, after that check it on online dictionary. Based on her opinion, videos and songs are one of the ways in acquiring new language, because she has high curiosity so that when she listen to the songs or watching the videos in language that she wanted to learn, she will find out the meaning of the songs or the words. From that way, she gradually acquired new vocabulary. As a beginner, learning through songs and videos are effective. In her experienced, she could remember and know few vocabularies and construct simple sentence. Yet, there are few disadvantages to learn a language by songs and videos, one of them is she could not learn the grammar. The language used in songs and videos sometimes not followingstandard grammar.

R2 got two correct answers, two false, and five unanswered. She has been watching Korean videos and listening to Korean songs for eight years or since junior high school. She has been always listening to Korean songs and videos every day. She wanted to learn Korean because she is a fan of Korean boy-group so that she could know what her idol is talking or writing about. She started to learn Korean since senior high, grade 11 and she found it was hard to write in Korean alphabet (Hangeul) because in writing Hangeul it uses different system unlike writing Indonesian or English alphabet. In her opinion, learning language through songs and videos is a good media; therefore we can enjoy the learning. The minus of this tool is, it is only works for receptive skills and it could make the learners passive as only listening and reading the subtitles or lyrics.

R3 got one correct answer, six wrong answers, and three unanswered. She has been watching Korean videos and listening to Korean songs for six years. Like the other two respondents, she is also listening to Korean songs or watching Korean videos every day. She likes to watch K-Pop, K-drama, and K-show. At first, she did not have any intention to learn the Korean language and culture, but she is exposed to the songs and videos every day and she started to learn Korean for a year. In her opinion, reading and writing in Hangeul is difficult since it is different from her native language (Indonesian) and Korean has its alphabet. If she encountered new vocabulary, she would look for it on the internet or online dictionary. In her opinion, the advantages of using songs and 
Pemerolehan Kosakata...

videos for learning language are the learner can acquire more vocabularies since the learners watch the videos and listen to the songs every day, so the learner might get new vocabulary and remember it subconsciously. The disadvantages are the learner could not learn the grammar or the form of the sentence since the learner only acquire words so we did not know how to arrange a sentence or combine the words.

\section{Korean Vocabulary Acquisition of Adult Learners}

The results of the present study showed that the vocabulary size is varied on every other participant. For R1, she got seven correct answers, R2 got two correct answers, and R3 got only one correct answer. It is in line with the result of the previous study by Susilowatik (2016) that is the students of Korean Language were also encountered difficulties in vocabulary. Susilowatik (2016) added in studying a language the learners need to practice a lot. Moreover, Korean language has its alphabet called Hangeul which needs extra effort for learners to learn. Thus to be successful in learning Korean language, the learners need to practice their Korean language skills.

An experiment by Yuka (2010) attempted to find the correlation between motivation and performance on vocabulary acquisition through reading found that students who joined extensive reading voluntarily achieved significantly higher compared to students who joined because in need to get additional score. Therefore, from previous study, motivation affects performance on vocabulary acquisition (cited in Nadiyah, 2014). Another previous study conducted by Hanifah (2014) entitled Uncovering Factors Related to Incidental Vocabulary Acquisition: an Experimental Study on Indonesian EFL Learners and also by Bintari (2017) entitled Frequency of Watching English Movies with Indonesian Subtitles and Sudents' Vocabulary Mastery, both of them found that students who have high frequency of watching English movies with Indonesian subtitles, they also have high enough vocabulary mastery, on the other word, it is positively correlated to each other variables.

All of the participants stated that they are exposed to Korean songs and videos for more than five years and have listened to Korean songs and watched Korean videos every day. They started to learn with mostly the same reason, because of Korean pop itself, but they were started to learn Korean language on different times. R1 and R2 started to learn Korean almost at the same time, but they got different results on the 
vocabulary test. R1 got high score on vocabulary test because she has learned through Korean songs and videos for five years and she was a high motivated learner. R2 got low score on vocabulary test although she has leaned Korean for more than five years. R1 explained how she dealt with new vocabulary, they would guess it first and correlate it with the context then directly check it on dictionary. Meanwhile, R2 and R3 would directly go to dictionary to check the meaning. Moreover, R3 started to learn Korean just a year ago.

Compared to the previous studies, although all of the participants in the present study were voluntarily learning Korean, it can be seen that they got different motivation for learning it. The result of this study is correlated to previous study. The higher the motivation on learner is the better result the learner's got. In order to become an active activity, watching movies has to be accompanied by the supportive activities. Supportive activities are writing down the newly acquired vocabulary, using dictionary to find the meaning, asking the expertise and friends, and using the newly acquired vocabulary in writing or speaking (Hanifah, 2014). Another difficulty encountered by participants is reading and writing Hangeul. Hangeul has 40 letters consisting of 14 consonants, 10 vowels, and 16 diphthongs and double consonants. The low score of R2 and R3 got might be because they were listening to the Korean content, but lack of exercising how to write the Hangeul and use it in both reading and writing.

The result of this study is in line with Saville-Troike (2006) stated on why some individuals got different result although has a common linguistics code. It can be looked such as background knowledge and experience, understanding of the overall situations, extra-linguistic content. This is why an individual may get better language acquisition than other. There is a positive correlation between the result of this study with the theory by Schumann (2013) stated it is obvious that L2 is not easily acquired by adult. Although all of them has exposed to Korean content media for more than five years, yet none of them got a perfect score in vocabulary test. This is also correlated to Johnson and Newport (1989) that older learners will not have native-like language skills, but will get a great attainment which different from each learner (cited in $\mathrm{Hu}, 2016$ ) in comparison between R1's score and R2's. Both of them have learned Korean for the same period, but R1's score is higher, it means that adult learners got different attainment from each other. 
The adult learners is able to acquire a new language, which in this present study is Korean language, through songs and videos within one-way communication yet difficult and complicated. The present study attempts to measure the effects of Korean songs and videos in one-way communication on vocabulary size of Korean language learners. Korean has specific alphabet called Hangeul which the learners need an extra effort to learn it. All of the participants said reading and writing Hangeul is difficult. In a nut shell, the acquisition of Korean language is started from learning on how to read and write in Hangeul.

\section{CONCLUSION}

In conclusion, vocabulary acquisition is difficult for adults because of motivation and their age factors. Although all of the participants in the present study were voluntarily learning Korean, it can be seen that they got different motivation for learning it. The higher the motivation on learner is the better result the learner's got. All participants of this study have exposed to Korean content media for more than five years, but only one participant got higher score than the other two participants. Thus, Korean vocabulary acquisition by listening to Korean songs and watching Korean videos is possible yet not easily acquired by adult.

Through this study, we found that there are difficulties encountered by the learners, especially adult learners in acquiring Korean vocabularies. This present study is only identifying the motivation and age factors in acquiring Korean vocabulary on adults. There are so many aspects affecting language acquisition other than motivation and age, such as environment, device, and mode. Therefore, a further study on Korean vocabulary acquisition and language acquisition on adult is needed by seeing on other factors or a deeper study on the factors which are used in this study.

\section{REFERENCES}

Bintari, F. (2017). Frequency of Watching English Movies with Indonesian Subtitles and Students' Vocabulary Mastery. Unpublished undergraduate thesis. Universitas Negeri Malang, Malang.

Deng, F., \& Zou, Q. (2016). A Study on Whether the Adults' SecondLanguage Acquisition Is Easy or Not-From the Perspective of Children's Native Language Acquisition. Theory and Practice in Language Studies, 6(4), 776-780. doi: http://dx.doi.org/10.17507/tpls.0604.15

Dulay, H., Burt, M., \& Krashen, S. (1982). Language Two. New York: Oxford University Press. 
Febriana, M. (2017). Building Early Childhood Learner's Vocabulary by Using BBC Learning English Video. In Rozimela, Y., Jufrizal, Fatimah, S., Amri, Z., Anwar, D., Refnaldi, et al. (Eds.), Challenges and Opportunities in Multi-Dimensional English Language Teaching in Changing EFL Contexts. Proceedings of the Fifth International Seminar on English Language and Teaching (ISELT-5) (pp. 97-100). Padang, Indonesia.

Teng, M. F. (2016). Development of Morphological Awareness through English Songs: A Case Study. Chinese Journal of Applied Linguistics, 39(2). doi: https://doi.org/10.1515/cjal2016-0011

Hanifah, M. (2014). Frequency of Watching English Movies with Indonesian Subtitles and Students' Vocabulary Mastery. Unpublished undergraduate thesis. Universitas Negeri Malang, Malang.

Hu, R. (2016). The Age Factor in Second Language Learning. Theory and Practice in Language Studies, 6(11), 2164-2168. doi: http://dx.doi.org/10.17507/tpls.0611.13

Nadiyah. (2014). Uncovering Factors Related to Incidental Vocabulary Acquisition: an Experimental Study on Indonesian EFL Learners. Unpublished undergraduate thesis. Universitas Negeri Malang, Malang.

Nugroho, S. (2010). Hallyu di Indonesia: Selama Dekade Pertama di Abad Ke-21. In Syamsuddin, M., Setiawan, N. A., Indrastuti, N. S. K., Nugroho, S. A., Seonhee, M., \& Dianawati, L. (Eds.), Sejarah Korea Menuju Masyarakat Modern: Beberapa Peristiwa Penting (pp. 49-67). Yogayakarta, Indonesia.

Purwiyanti, Y., Suwandi, S., Andayani. (2017). Strategi Komunikasi Pemelajar Bahasa Indonesia bagi Penutur Asing (BIPA) Asal Filipina. Ranah: Jurnal Kajian Bahasa, 6(2), 160-179. DOI: https://doi.org/10.26499/rnh.v6i2.448

Saville-Troike, M. (2006). Introducing Second Language Acqusition. Cambridge: Cambridge University Press.

Schumann, J. (2013). Societal Responses to Adult Difficulties in L2 Acquisition: Toward an Evolutionary Perspective on Language Acquisition. Language Learning: A Journal of Research in Language Studies, 63(1).

Susilowatik, A. (2016). Kesulitan Mahasiswa Program Studi D3 Bahasa Korea Sekolah Vokasi Universitas Gadjah Mada dalam Belajar Bahasa Korea. Unpublished final project. Universitas Gadjah Mada, Yogyakarta.

Verstegen, S. (2014). Receptive Vocabulary Development of Children Acquiring Chinese, Swedish and Korean as Measured by the PPVT-4. Unpublished undergraduate thesis. Utrecht University, Netherlands. Retrieved from https://dspace.library.uu.nl/bitstream/handle/1874/297052/Scriptie\%20Saskia\%20Verstegen.pdf?sequence=2 